\title{
NEGARA DALAM PEMIKIRAN MOHAMMAD NATSIR
}

Oleh:

\author{
Mhd. Alfahjri Sukri
}

Institut Agama Islam Negeri Batusangkar, Indonesia

Email: malfahjrisukri@iainbatusangkar.ac.id

\begin{abstract}
Abstrak
Penelitian ini bertujuan untuk melihat bagaimana pemikiran Mohammad Natsir tentang negara dan faktor-faktor yang mempengaruhi munculnya pemikiran tersebut. Metode yang digunakan yaitu metode kualitatif dengan memberikan gambaran dan mengalisis pemikiran Natsir tentang negara. Data penelitian ini diperoleh dari analisis dokumen dan studi literatur. Hasil penelitian menunjukkan, Negara dalam pemikiran Natsir berfungsi sebagai alat dalam menjalankan syariat Islam. Menurutnya, dengan Islam, negara akan memiliki akar yang kuat. Mengenai bentuk negara, Natsir tidak terpaku dengan bentuk negara apapu, baginya bentuk apa saja boleh asalkan syariat Islam dijalankan. Natsir juga tidak mensyaratkan seorang kepala negara menggunakan label khalifah dan tidak harus dari keturunan Quraish. Adapun beberapa faktor yang mempengaruhi pemikiran Natsir mengenai negara yaitu pengaruh lingkungan kecil Natsir yang lahir di Minangkabau, pengaruh dari tokoh ulama nasional secara langsung dan tokoh ulama internasional secara tidak langsung (bacaaan), sosialisasi politiknya di organisasi dan partai Islam serta konteks politik Indonesia saat itu.
\end{abstract}

Kata Kunci: Mohammad Natsir, Islam, Negara, Indonesia

\section{A. PENDAHULUAN}

Ragam dan corak pemikiran mengenai negara selalu menjadi kajian menarik untuk didalami, termasuk di Indonesia. Pemikiran mengenai negara di Indonesia sendiri sudah menjadi perbincangan hangat bahkan sebelum Indonesia merdeka. Ragam pemikiran tersebut telah banyak melahirkan tokoh-tokoh nasional seperti Soekarno dengan corak pemikiran nasionalisnya, D.N Aidit dengan corak komunisnya dan Mohammad Natsir dengan corak pemikiran keIslamannya.

Sebagai negara yang mayoritas beragama Islam pada masa itu (kemerdekaan), telah melahirkan banyak pemikir Islam yang telah memberikan banyak konstribusi bagi Indonesia. Corak pemikiran para tokoh tersebut sangat beragam karena dipengaruhi oleh latar belakang keagamaan dan lingkungan mereka. Islam di Indonesia sendiri memang sangat beragam, ada yang tradisionalis, moderat bahkan puritan. Semua 
bercampur aduk dan melahirkan banyak pemikiran yang beragam.

Melihat banyaknya penganut agama Islam di Indonesia, para pemikir Islam tersebut sadar akan perlunya negara berdasarkan Islam, terutama pada masa awal kemerdekaan Indonesia. Dalam memperjuangkan Islam sebagai dasar negara, ada yang mengambil langkah radikal dan ada yang mengambil langkah moderat. Tokoh yang mengambil langkah radikal seperti yang dilakukan oleh Kartosoewirjo dalam memperjuangkan Negara Karunia Allah-Negara Islam Indonesia (NKA-NII) yang biasa disebut dengan DI-TII (Darul IslamTentara Islam Indonesia). Adapuun yang mengambil langkah moderat dengan tetap menjaga keutuhan NKRI (Negara Kesatuan Republik Indonesia) adalah seperti yang dilakukan oleh Mohammad Natsir.

Walaupun Natsir mengambil langkah moderat dalam mengimplementasikan pemikirannya tentang negara yaitu Islam sebagai dasar negara, masih banyak yang beranggapan bahwa Natsir ingin mendirikan negara Islam dan menolak Pancasila. Dzulfikriddin (2010) dalam bukunya yang berjudul "Mohammad Natsir Dalam Sejarah Politik Indonesia" menjelaskan, perjuangan Mohammad Natsir dalam menjadikan Islam sebagai dasar negara mendapatkan penentangan dari kalangan nasionalis dan non Islam, terutama ketika Natsir memperjuangkannya di Konstituante. Konsekuensi dari pemikiran dan kritik Natsir terhadap Soekarno berakibat pada terancamnya keselamatan Natsir beserta keluarga, sehingga Natsir harus menyelamatkan diri ke Sumatera Barat pada akhir 1957.
Pemikiran Natsir tentang negara dan keberaniannya dalam menyalurkan aspirasinya untuk menjadikan Islam sebagai dasar negara, banyak disalahpahami oleh orang-orang yang tidak senang kepada Islam. Banyak yang mengatakan, Natsir berupaya untuk mendirikan negara Islam dan tidak mengakui Pancasila sebagai dasar negara. Padahal kalaulah Natsir ingin menjadikan Islam sebagai dasar negara secara paksa, maka ia bisa melakukannya ketika menjadi Perdana Menteri (PM) pada 1950-1951 (Dzulfikriddin, 2010). Bahkan selaku PM, Natsir tidak segan-segan mengambil tindakan tegas terhadap kelompok Darul Islam (DI/TII) Kartosuwiryo yang ingin mendirikan negara Islam di Indonesia secara inkonstitusional. Pemikiran tentang Islam sebagai dasar negara republik Indonesia baru ia perjuangkan melalui Konstituante. Namun setelah Konstituante dibubarkan, Natsir tidak lagi lantang dalam menyuarakan pemikiran kenegaraannya yaitu Islam sebagai dasar negara.

Penelitian mengenai Mohammad Natsir sendiri sebelumnya telah banyak dilakukan oleh penelitipeneliti lain seperti Emi Sutyaningsih, Susilo Surahman, Yusafrida dan peneliti lainnya. Emi Sutyaningsih (2016) dalam tulisannya yang berjudul Perjuangan dan Pemikiran Politik Mohammad Natsir (1907-1993), selain menjabarkan sejarah dan kiprah Mohammad Natsir dalam politik Indonesia, ia juga menjelaskan pemikiran Natsir tentang agama dan negara, khususnya Islam dan Pancasila. Ia memaparkan bagaimana perubahan pemikiran Natsir tentang Pancasila. Kajian yang menitikberatkan pada sejarah ini juga dilakukan oleh 
Yulsafrida (2012) yang dalam penelitiannya hanya memotret kiprah Natsir secara umum dalam politik serta menjelaskan secara deskriptif pemikirannya Mohammad Natsir tentang negara. Penjelasan secara umum mengenai Mohammad Natsir juga dilakukan oleh Susilo Surahman yang mencoba membandingkan pemikiran Mohammad Natsir dengan Nurcholish Madjid dalam penelitiannya yang berjudul Islam dan Negara menurut M. Natsir dan Nurcholish Madjid.

Penelitian yang dilakukan oleh Emi Sutyaningsih, Susilo Surahman dan Yusafrida tersebut belum mengalisis secara mendalam mengenai pemikiran Mohammad Natsir tentang negara, khususnya tentang Islam dan negara. Penjabaran yang dilakukan penelitian terdahulu hanya sebatas pada kiprah dan paparan sejarah, padahal dalam mengkaji pemikiran pemikiran seseorang juga perlu melihat faktor penyebab munculnya pemikiran tersebut yang dapat dilihat dari sosialisasi politik yang dilalui oleh Natsir serta konteks politik saat itu.

Dalam penelitian yang berjudul "Negara Dalam Pemikiran Mohammad Natsir", peneliti menjelaskan tidak hanya sejarah Mohammad Natsir tetapi juga menganalisis pemikirannya tentang negara serta faktor-faktor yang mempengaruhi pemikirannya tersebut.

\section{B. METODE PENELITIAN}

Penelitian ini merupakan penelitian kualitatif dengan jenis penelitian eksplanatif. Menurut Sugiyono (2012 : 2) metode penelitian kualitatif adalah Metode penelitian yang berlandaskan pada filsafat postpositivisme, digunakan untuk meneliti pada kondisi objek yang alamiah, (sebagai lawannya eksperimen) dimana peneliti adalah sebagai instrumen kunci, teknik pengumpulan data dilakukan secara triangulasi (gabungan), analisis data bersifat induktif/kualitatif, dan hasil penelitian kualitatif lebih menekankan makna dari pada generalisasi.

Ada beberapa cara mengumpulkan data dalam penelitian kualitatif yaitu observassi, analisis dokumen, analisis percakapan dan analisis diskursus. Dalam penelitian ini, penulis menggunakan metode analisis dokumen. Ritchie dan Lewis menyebutkan bahwa analisis dokumen adalah pengkajian terhadap berbagai dokumen seperti dokumen-dokumen umum, dokumen-dokumen prosedural ataupun dokumen-dokumen pribadi seperti catatan harian. Kajian dokumen ini dilakukan tidak hanya untuk memahami isi dari dokumen-dokumen, tetapi juga untuk menangkap maknamakna yang tersimpan di balik isi dokumen tersebut (Ritchie \& Lewis, 2003).

Dengan metode kualitatif, penelitian bersifat felksibel dan dapat beradaptasi dengan perubahanperubahan yang ada. Melalui metode kualitatif, peneliti menggali, mendeskripsikan dan menggambarkan secara sistematis pemikiran Mohammad Natsir mengenai negara, khususnya pandangannya tentang Islam dan negara serta faktor-faktor yang mempengaruhi pemikirannya. Melalui metode kualitatif diharapkan mampu menghasilkan data-data yang menjawab pertanyaan dari identifikasi masalah.

\section{PEMBAHASAN}


Sejarah Singkat Mohammad Natsir Mohammad Natsir adalah cendikiawan, pejuang, politikus, ulama, sekaligus negawaran Indonesia. Ia merupakan salah tokoh Islam yang sangat disegani di Indonesia dan dunia internasional melalui pemikiran, tindakan dan karya-karyanya. Mohammad Natsir juga merupakan salah satu tokoh perumus ide tentang Islam sebagai dasar negara.

Mohammmad Natsir dilahirkan di kampung jembatan berukir Alahan Panjang, Kabupaten Solok, Sumatera Barat pada tanggal 17 juli 1908. Di kota ini terdapat suatu norma berupa folkways yang berfungsi mensosialisasikan seorang anak agar belajar hidup mandiri dan menghayati nilai-nilai dasar Islam dan adat istiadat (Suhelmi, 2002: 30). Berasal dari keluarga Minangkabau ternyata juga mempengaruhi kehidupan keIslaman Mohammad Natsir sejak kecil, karena falsafah hidup orang Minang yaitu "Adat Basandi Syara', Syara' Basandi Kitabullah" yang tidak dapat dipisahkan dalam kehidupan seharihari orang Minangkabau.

Nilai-nilai keIslaman yang ada di Minangkabau sudah tersosialisasi dalam diri Natsir. Hal ini dipengaruhi oleh faktor kondisional dan lingkungan sosio-kultural. Faktor kondisional dilihat pada kuatnya gagasan-gagasan pembaharuan Islam dalam masyarakat Alahan Panjang yang mendorong Natsir untuk mengenal gagasangagasan pembaruan Islam. Adapun faktor sosio-kultural berkaitan dengan tempat Natsir dilahirkan yang akan mempengaruhi pikiran dan tingkah laku Natsir (Suhelmi, 2002: 30).

Dalam perjalanan sejarah Indonesia, Mohammad Natsir telah banyak memberikan kontribusi, baik itu dalam hal tindakan maupun pikiran. Kontribusi Mohammad Natsir bagi Negara Republik Indonesia seperti meletakkan dasar-dasar Kementerian Penerangan ketika menjabat sebagai Menteri Penerangan 4 kali yaitu pada masa kabinet Syahrir I (3 Januari-12 Maret 1945), Syahrir II (12 Maret-3 Oktober 1946), Syahrir III (2 Oktober 1946-3 Juli 1947), Hatta (29 Januari 1948-4 Agustus 1949), serta berhasil membujuk presiden PDRI (Pemerintahan Darurat Republik Indonesia) Sjafruddin Prawiranegara untuk memberikan mandat pada Soekarno.

Ketika Indonesia berbentuk negara RIS (Republik Indonesia Serikat) pada tanggal 27 Desember 1949, Mohammad Natsir yang menjabat sebagai anggota DPR-RIS sekaligus Ketua Fraksi Masyumi, menyampaikan pidato di hadapan Sidang Parlemen RIS pada 3 April 1950 yang kemudian dikenal dengan "Mosi Integral Natsir" (Mahfud, 2008: 8). Melalui mosi inilah Indonesia kembali bersatu menjadi Negara Kesatuan Republik Indonesia (NKRI).

Dzulfikriddin (2010) mencatat, setelah kembalinya Indonesia kepada bentuk negara kesatuan, pada tanggal 20 Agustus 1950 presiden Soekarno menggunakan hak prerogatifnya dengan menunjuk Mohammad Natsir sebagai Perdana Menteri. Kabinet bentukan Natsir tanpa mengikutkan PNI, dan dalam kabinet ini diikutsertakan lima orang tokoh nonpartai serta jabatan menteri yang diberikan pada orang yang ahli dalam bidangnya sehingga kabinet ini disebut dengan Zaken Kabinet. Pada 21 Maret 1950 Mohammad Natsir memberikan mandatnya pada presiden dan tuganya 
sebagai Perdana Menteri selesai pada tanggal 27 April 1950.

Setelah itu Mohammad Natsir aktif di Konstituante setelah terpilih pada pemilu 1 di Indonesia tahun 1955. Sebenarnya Natsir juga terpilih menjadi anggota DPR daerah pemilihan Jawa Barat, namun karena ada ketentuan tidak boleh merangkap di dua lembaga itu, maka Natsir lebih memilih untuk duduk di Konstituante karena melalui lembaga inilah Natsir bisa mengeluarkan gagasannya terkait Islam sebagai dasar negara Republik Indonesia.

Pada Tahun 1958 Natsir bergabung dengan PRRI (Pemerintah Revolusioner Republik Indonesia) sebagai tindakan untuk mengingatkan Soekarno agar kembali ke UUD 1945. Dan pada tahun 1980 ikut dalam petisi 50 pada masa Orde Baru bersama tokoh-tokoh lainnya.

Walaupun memiliki pandangan yang berseberangan dengan Soekarno maupun Soeharto serta menjadi tahanan politik pada masa tersebut, Natsir tetap memberikan kontribusi bagi Indonesia. Pada masa Soeharto, Natsir memiliki peranan penting dalam memperbaiki hubungan antara Indonesia dengan Malaysia yang rusak pada masa Orde Lama. Dalam hal ini Natsir memliki hubungan yang baik dengan Perdana Menteri Malaysia Tengku Abdul Rahaman. Melalui Natsir, utusan Indonesia akhirnya diterima oleh Perdana Menteri Malaysia Tengku Abdul Rahman yang sebelumnya menolak utusan dari Indonesia (Tempo, 1993: 104-105).

Natsir juga berperan dalam membantu pemerintah Orde Baru dalam mencairkan kredit luar negeri salah satunya adalah Jepang. Natsir meyakinkan pemerintah dan pengusaha
Jepang untuk memberikan bantuan kredit kepada pemerintah RI dan menenanamkan Investasinya di Indonesia. Peranan Natsir ini diakui oleh Fukuda (Mantan PM dan Menkeu Jepang) (Dzulfikriddin 2010: 157). Dan banyak lagi kontibusi yang tetap diberikan Natsir untuk Indonesia, walaupun ia menjadi tahanan politik pada masa tersebut.

Ketika karir politiknya mati, Natsir menfokuskan dirinya dibidang dakwah dengan mendirikan Dewan Dakwah Islam Indonesia pada 26 Februari 1967 setelah halal bi halal keluarga besar Bulan Bintang di Mesjid Al-Muwarrah Tanah Abang. Tujuan dari didirikan DDII ini adalah untuk meningkatkan dan menggiatkan mutu dakwah Islamiyah Indonesia Melalui DDII inilah Natsir pernah menduduki jabatan di berbagai organisasi Islam di dunia seperti World Muslim Congress, Rabitah Alam Islamy (1969), Anggota Dewan Mesjid Sedunia dan lain-lain (Mohammad dkk, 2006: 52).

Selain memiliki kiprah politik nasional, Mohammad Natsir juga dikenal dengan kiprahnya di dunia internasional serta karya-karyanya. Di kancah internasional, pada tahun 1956, Natsir bersama Syekh Abul A'la alMaududi (Lahore) dan Abu Hassan anNawadi (Lucknow) memimpin sidang Muktamar Alam Islamy di Arab Saudi. Natsir juga dikenal dengan dukungannya terhadap kemerdekaan bangsa-bangsa Islam di Asia dan Afrika. Natsir juga sering diminta nasehat dan pandangannya oleh tokohtokoh PLO (Palestine Liberation Organisation), mujahidin Afganisthan, Moro, Bosnia, dan juga tokoh politik non muslim dari Jepang dan Thialand (Luth, 1999: 26). 
Natsir juga mendapatkan penghargaan Internasional seperti penghargaan Internasional berupa Bintang Penghargaan dari Tunisia dan dari Yayasan Raja Faisal Arab Saudi (1980). Natsir juga menerima gelar Doktor Honoris Causa dari Universitas Islam Malaysia Lebanon (1967) dalam bidang Sastra, dari Universitas Kebangsaan Malaysia dan Universitas Saint Teknologi Malaysia (1991) dalam bidang pemikiran Islam (Luth, 1999: 27).

Pada tanggal 6 Februari 1993, Natsir dipanggil kehadirat Ilahi di rumah sakit Cipto Mangunkusumo, Jakarta, dalam usia 85 tahun. Berita duka ini menjadi bahan utama diberbagai media cetak. Ucapan belasungkawa datang dari berbagai orang atas kepergian Natsir, salah satunya datang dari Mantan Perdana Menteri Jepang yang diwakili oleh Nakadjima.

Dzulfikriddin

(2010)

menyatakan, tidak banyak para sejarawan yang mencatat tentang banyaknya kontribusi Mohammad Natsir bagi Indonesia, bahkan masih banyak terdapat dalam buku-buku sejarah yang mengatakan bahwa Natsir adalah pemberontak. Padahal bisa dikatakan Natsir merupakan salah satu orang yang sangat berpengaruh dalam menjaga keutuhan Republik Indonesia.

\section{Negara dalam Pemikiran Mohammad Natsir}

Berbicara mengenai hubungan Islam dan negara, para ahli memiliki pendapat yang berbeda-beda. Ada yang berpendapat bahwa Islam sangat erat hubungannya dengan negara sehingga Islam juga mewajibkan pendirian negara yang berazazkan Islam, namun ada juga yang berpendapat bahwa Islam dan negara itu tidak memiliki hubungan sama sekali, atau bisa dikatakan bahwa Islam hanya mengatur hubungan antara manusia dengan tuhannya, dengan alasan Islam tidak memiliki struktur negara yang jelas serta perkembangan zaman yang sudah mulai memisahkan antara negara dan agama.

Para ahli atau ulama seperti Syeikh Ali Abd Al-Raziq, Nurcholis Majid, Munawir Sjadzali dan Soekarno adalah yang berpendapat bahwa Islam tidak ada hubungannya dengan negara sehingga negara Islam itu tidak perlu ada. Syeikh Ali Abd Al-Raziq dalam bukunya The Principles of Government (Al Islam wa Ushul Al Hukm) berpendapat, Al-Qur'an dan Hadist tidak menyebutkan perlunya negara Islam. Raziq berpendapat bahwa misi Nabi hanyalah tujuan spiritual, bukan untuk mendirikan negara atau pemerintahan (Jameelah, 1982).

Munawir

Sjadzali berpandangan, Islam tidak memiliki preferensi terhadap sistem politik yang mapan, dengan kata lain Islam tidak memiliki sistem politik. Islam hanyalah berisi perangkat tata nilai etis yang dapat dijadikan pedoman dalam penyelenggaraan negara. Sjadzali menjelaskan, dalam Al-Qur'an tidak ada pembahasan mengenai sistem politik (Thaha, 1996). Soekarno juga memilki jalan pikiran yang sama dengan tokoh-tokoh di atas, bahkan ia menjadikan Turki era kepemimpinan Mustafa Kemal sebagai contoh negara sekuler yang dapat ditiru oleh Indonesia.

Adapun para ahli atau ulama yang berpendapat bahwa Islam memiliki hubungan yang erat dengan negara (Islam juga mengatur kehidupan 
bernegara dan pemerintahan, bukan hanya mengatur hubungan antara manusia dan tuhan semata) yaitu seperti Abul A'la Al-Maududi, Hassan Al-Banna, Sayyid Qutb, A. Hasjmy, Al-Mubarak dan Mohammad Natsir sendiri.

\section{Al-Maududi}

berpandangan, sumber hukum yang ada dalam masyarakat muslim bersumber dari kehendak Tuhan, bukan manusia. Pedoman dari hukum tersebut yaitu AlQur'an dan Sunnah Rasulullah yang kemudian dinamakan syariah. Menurut Al Maududi, masyarakat muslim terikat untuk mengikuti syariah karena adanya kontrak yang terbentuk.

Hassan Al-Banna, pimpinan Ikhawanul Muslimin di Mesir berpandangan, Islam merupakan tatanan lengkap bagi semua kehidupan. Islam adalah negara dan bangsa atau pemerintahan dan masyarakat, moral dan kekuasaan. Islam adalah aqidah yang benar, satu sama lain saling melengkapi dan sama derajatnya (Sirajuddin, 2007: 22). Pandanganpandangan tokoh Islam tersebut selaras dengan pandangan Mohammad Natsir tentang Islam dan negara, namun dalam hal ini Natsir lebih bersikap moderat.

Natsir sendiri memberikan pandangannya mengenai suatu negara berkaitan dengan pengertiannya, syarat dari suatu negara dan kedudukan dari negara itu. Menurut Natsir, negara adalah suatu "institution" yang mempunyai hak, tugas dan tujuan yang khusus. Institution menurut Natsir adalah suatu badan dan organisasi yang mempunyai tujuan khusus serta dilengkapi oleh alat-alat material dan peraturan-peraturan tersendiri, dan diakui oleh umum (Santoso, $2004: 22$ ).
Institution dalam pandangan Natsir adalah suatu badan yang memiliki syarat-syarat seperti, a) bertujuan untuk mencukupi kebutuhan masyarakat di bidang jasmani maupun rohani, b) diakui oleh masyarakat, c) mempunyai alat-alat untuk melaksanakan tujuan, d) mempunyai peraturan-peraturan, dan norma-norma dan nilai-nilai tertentu, e) berdasarkan atas faham hidup, f) mempunyai kedaulatan atas anggotanya, i) memberikan hukuman terhadap setiap pelanggaran atas peraturan-peraturan dan norma-normanya (Santoso, 2004 : 23).

Adapun cangkupan kedudukan negara menurut Natsir yaitu 1) meliputi seluruh masyarakat dan segala institution yang terdapat didalamnya, 2) mengikat ataupun mempersatukan institution-institution tersebut dalam suatu peraturan hukum, 3) menjalankan koordinasi dan regulasi dari seluruh bagian-bagian masyarakat, 4) memiliki hak-hak untuk memaksa anggotanya mengikuti peraturan-peraturan dan hukum-hukum yang ditentukan olehnya, 5) mempunyai tujuan untuk memimpin, memberi bimbingan dan memenuhi kebutuhan masyarakat secara keseluruhan (Santoso, 2004 : 23-24).

Dalam pemikiran Natsir, suatu negara harus mampu menjamin kehidupan masyarakatnya, memiliki pemerintahan dan kedaulatan serta undang-undang yang mengatur kehidupan masyarakat. Dasar dari suatu negara haruslah kuat, agar undang-undang dasar negara Indonesia bisa menjamin negara memiliki hubungan yang sangat erat dengan masyarakat yang hidup di dalamnya, dan ia adalah Islam. Natsir mengutip pandangan Ibnu Khaldun : 
"Nyatalah bagi kita bahwa negara itu harus memiliki akar yang tertanam kuat dalam masyarakat. Oleh karena itu dasar negarapun harus suatu faham hidup, yang dijalankan sehari-hari, yang jelas dan dapat dipahami. Pendek kata, yang menyusun hidup sehari-hari bagi rakyat, baik secara perorangan maupun kolektif." (Santosa, $2004: 24$ )

\section{Natsir mengambil Islam sebagai dasar negara dikarenakan ia berpendapat bahwa Islam memiliki ajaran yang lengkap meliputi seluruh aspek kehidupan baik Individu maupun masyarakat. Menurutnya, Islam memiliki ajaran-ajaran tentang ketatanegaraan dan sosial masyarakat yang lengkap dan sempurna, bukan hanya bagi umat Islam namun juga bagi agama lain karena Islam bersifat universal "rahmatan lil 'alamin".}

Pengertian, syarat-syarat dan kedudukan negara dalam pandangan Natsir masih memiliki persamaan dengan tokoh-tokoh barat atau tokohtokoh sekuler. Perbedaannya adalah tentang pandangan mengenai kedudukan Islam dalam suatu negara, dan hal inilah yang kemudian menjadi perdebatan sampai saat ini.

Bagi Natsir, Islam memiliki peraturan-peraturan hukum yang mengatur kehidupan masyarakat, bukan hanya untuk orang-orang Islam. Peraturan-peraturan hukum tersebut akan berjalan dengan adanya negara karena negara sebagai alat untuk berjalannya hukum-hukum tersebut secara tertib. Sehingga dalam hal ini Natsir memandang bahwa Islam dan negara bukanlah suatu hal yang terpisahkan.
Menurut Natsir, dalam Islam tidak akan ditemukan peraturanperaturan detail yang bersifat teknis, yang ada adalah patokan-patokan atau batasan-batasan dalam peraturan tersebut, dan dasar-dasar pokok tersebut, menurut Natsir bersifat abadi dan tidak dapat diubah karena batasan atau patokan tersebut lansung bersumber dari wahyu langit (Allah) (Santosa, 2004: 60).

Perjuangan dalam menegakkan Islam dilakukan Natsir secara konstitusional, berbeda dengan Kartosoewirjo yang melakukan gerakan separatis untuk mendirikan Negara Islam Indonesia (NII). Hal ini terlihat dari tindakan Natsir ketika menjadi perdana menteri dalam membujuk Kartosoewirjo (NII) untuk menghentikan pemberontakan dan mengajaknya untuk memperjuangkan Islam secara konstitusional.

Negara dalam pandangan Natsir hanya sebagai alat untuk memberlakukan syari'at-syari'at Islam. Negara berdiri dengan atau tanpa Islam. Sehingga tidak perlu ada perintah yang tegas untuk mendirikan negara, yang dibutuhkan adalah patokan-patokan dalam mendirikan negara dan hal itu dalam pandangan Natsir sudah dipraktekkan oleh Rasululah.

Dalam pemilihan kepala negara, Natsir (1973) tidak terpaku pada keharusan memakai nama khalifah dan harus keturunan Quraisy. Bagi Natsir gelar apapun boleh digunakan seperti khalifah, amirul mukminin, presiden dan lain-lain. Kriteria untuk mejadi pemimpin menurut Natsir adalah dengan dilihat dari agamanya, sifat, tabiat, akhlak dan kecakapan dalam memangku jabatan, bukan pada bangsa dan keturunannya. 
Adapun bentuk negara yang ada dalam pemikiran Natsir adalah bebas asalkan syari'at-syari'at Islam itu ditegakkan. Namun, penelitian ini melihat Natsir lebih condong ke bentuk negara kesatuan. Bentuk negara kesatuan sangat diinginkan oleh Natsir, hal ini didukung oleh tindakan dan ucapanucapan Natsir sendiri.

Tindakan yang nyata telah dilakukan oleh Natsir dan tokoh-tokoh lain dalam menjadikan Indonesia menjadi negara kesatuan yang sebelumnya berbentuk negara federal. Bentuk ketidaksatuan ini menurut pandangan Natsir bertentangan dengan nilai-nilai Islam, karena dalam Islam mengajarkan untuk bersatu. Natsir mengecam bentuk negara federal yang dapat memecah belah Indonesia, oleh karena ia melobi tokoh-tokoh politik di seluruh Indonesia untuk kembali bersatu. Dalam upayanya menjadikan Indonesia menjadi negara kesatuan, Natsir mengeluarkan sebuah mosi yang dikenal dengan nama "mosi integral" di Parlemen RIS (Republik Indonesia Serikat). Dengan mosi integral inilah Indonesia kembali menjadi negara kesatuan.

Kecenderungan Natsir dalam memilih bentuk negara kesatuan disebabkan oleh beberapa hal seperti niat jahat Belanda untuk kembali memecah Republik Indonesia dengan membentuk negara-negara boneka yang tergabung dalam Republik Indonesia Serikat, sehingga menurut Natsir niat jahat Belanda tersebut harus dilawan dengan persatuan. Dan bentuk negara kesatuan diinginkan Natsir karena Islam mengajarkan nilai-nilai persatuan dan toleransi.

\section{E. Faktor-Faktor Mempengaruhi Natsir tentang Negara \\ yang Pemikiran}

Lahirnya pemikiran Natsir mengenai negara tentunya tidak muncul secara tiba-tiba. Pemikiran tersebut lahir dari suatu proses berpikir yang panjang yang dipengaruhi oleh banyak hal. Penelitian ini melihat, beberapa faktor yang mempengaruhi pemikiran Natsir mengenai negara yaitu pengaruh lingkungan masa kecil Natsir, (kondisional dan sosio-kultural) di Minangkabau, pengaruh tokoh-tokoh nasional (Ahmad Hassan, H.Agus Salim, Syeikh Ahmad Syurkati dan H.O.S Tjokroaminoto) secara lansung, pengaruh dari tokoh internasional secara tidak lansung melalui bacaan (Hassan Al-Banna, Amir Syakib Arselan, Rasyid Ridha dan Muhammad Abduh), pengaruh organisasi dan partai politik tempat Natsir bernaung (Jong Islamieten Bond (JIB), Persatuan Islam (Persis), dan partai politik Masyumi), serta pengaruh dari kondisi perpolitikan saat itu.

Berkembangnya ajaran Islam di Minangkabau membawa pengaruh bagi kehidupan masyarakat Minang, terutama setelah lahirnya "Traktat Marapalam". Traktat marapalam merupakan hasil kesepakatan antara kaum adat dan kaum alim ulama setelah terjadinya perang Paderi (18031838) yang berawal dari gerakan pemurnian agama yang dimotori oleh Haji Miskin, Haji Sumanik, dan Haji Piobang. Isi rumusan konsensus itu berbunyi: "Adat Basandi Syara" Syara" Basandi Kitabullah" (ABS SBK). Konsensus ini menjadi energi yang menyalakan spirit perubahan orang Minang yang tetap berakar pada budayanya. Melalui konsensus inilah 
nilai-nilai Islam semakin melekat dalam masyarakat Minangkabau. Dan melalui konsensus ini juga melahirkan konsep yang disebut tungku tigo sajarangan, yakni ninik mamak, alim ulama, dan cerdik pandai. Dalam konsep tersebut, alim ulama memiliki peranan penting dalam masyarakat Minang.

Mohammad Natsir merupakan salah satu putra minangkabau yang menjadi tokoh nasional. Ia dilahirkan pada 17 Juli 1908 dari pasangan Sutan Saripado dan Khadijah, yang merupakan anak ketiga dari empat bersaudara. Ia lahir disebuah kota yang bernama Alahan Panjang, Sumatera Barat. Di Sumatera Barat $^{1}$ jugalah banyak lahir tokoh-tokoh nasional seperti Agus Salim, Mohammad Hatta, Hamka dan Sutan Syahrir.

Lahir dari keluarga religius dan lingkungan adat Minangkabau yang memiliki falsafah hidup "Adat Basandi Syara', Syara' Basandi Kitabullah”, merupakan sosialisasi awal bagi keagamaan dan intelektual Natsir. Lingkungan keluarga tempat Natsir dibesarkan sangat mementingkan pendidikan dan taat dalam menjalankan agama. Kakeknya seorang ulama besar

\footnotetext{
1 Minangkabau merupakan salah satu suku bangsa di Indonesia yang mementingkan pendidikan. Santosa mengatakan, Minangkabau merupakan satu dari sekitar 140 kelompok etnis yang menempati keseluruhan kepulauan Indonesia, dan pada tahun 1907 telah lahir untuk pertama kalinya sekolah yang dibangun oleh swadaya masyarakat. Dan ketika pemerintah Belanda membuka sekolah di Sumatera Barat pada tahun 1909, lebih dari sepertiga murid-muridnya adalah anak-anak pibumi Minangkabau. Pada tahun 1914 terdapat Sekolah Dokter Jawa (STOVIA) yang 25 persen siswanya adalah anak-anak Minangkabau. Lihat, Kholid O. Santosa. (2004). Mohammad Natsir Islam Sebagai Dasar Negara. Bandung: Sega Arsy.
}

di Minangkabau dan sanak keluarganya banyak yang bekerja di aparat pemerintahan. Hal ini jugalah yang nantinya akan menentukan perkembangan pemikiran Natsir, selain dari lingkungan adat Minangkabau itu sendiri yang kental dengan nilai-nilai yang Islami. Dalam seri buku mengenai Natsir yang diterbitkan oleh Tempo (2011: 10), dikatakan, semasa kecil, Natsir sering menghibiskan waktunya ke surau (kebiasaan orang Minang dahulu) untuk mengaji, dan bahkan semasa kanak-kanaknya hampir setiap malam ia memilih tidur di surau.

Natsir memulai pendidikannya di Hollands Inlandse School Adabiyah Padang, dan kemudian pindah ke HIS Solok. Di Soloklah Natsir mulai belajar bahasa Arab dan belajar hukum fikih dengan Tuanku Mudo Amin yang dilakukan pada sore hari di Madrasah Diniyah dan mengaji Al-Qur'an pada malam harinya (Luth,1999 : 22). Ketika di MULO Padang dan Algemene Middlelbare School Westers Klasieke Afdeling (AMS A2) Bandung, Natsir sudah banyak menyerap pemikiran-pemikiran keagamaan tokoh pembaharuan Islam seperti Ahmad Hassan, Agus Salim, H.O.S Tjokroaminoto, dan Syeikh Ahmad Syukarti yang nantinya akan mempengaruhi gaya berpikir Natsir.

Ketika masih di MULO Padang, pemikiran Natsir di bidang politik-kenegaraan dan demokrasi mulai terbentuk setelah ia aktif di pandu Nasional Islamische Padvindrij (Natipij), yang merupakan bagian dari Jong Islamieten Bond (JIB) cabang Padang.

Lingkungan di Sumatera Barat (alam Minangkabau) merupakan sosialisasi awal bagi terbentuknya prilaku dan gaya pemikiran Natsir 
tentang negara. Keluarga yang religius dan keturunan salah satu ulama di Sumatera Barat serta kebiasaan mengaji dan tidur di surau mengakibatkan nilai-nilai Islam dalam diri Natsir sudah tertanam dengan baik. Semua ini nantinya akan berkembang ketika Natsir berada di Bandung, yang mana waktunya dihabiskan tidak hanya menimba ilmu dunia, namun juga ilmu akhirat serta membaca buku-buku karangan ulama internasional dan berguru dengn ulama dan tokoh-tokoh nasional yang ada di Bandung. Gaya berpikir Natsir semakin terasah ketika ia memasuki berbagai organisasi yang ada di Indonesia terutama Persatuan Islam (Persis) yang dipimpin oleh Ahmad Hassan dan Jong Islamieten Bond (JIB) Bandung yang memiliki tokoh-tokoh terkenal seperti Agus Salim, H.O.S Tjokroaminoto dan lainlain.

Selama masih belajar di AMS, Natsir juga aktif dalam organisasi Jong Islamieten Bond (JIB) Bandung, dan bahkan ia menjadi ketua JIB Bandung periode 1928-1932. JIB Bandung merupakan organisasi tempat pertama kali Natsir belajar politik. Melalui organisasi ini Natsir bertemu dengan tokoh-tokoh pergerakan Islam dan teman-teman seperjuangannya di Masyumi kelak, seperti Prawoto Mangkusasmito, Mohammad Roem, Syafruddin Prawiranegara dan lainlain. Haji Agus Salim, Syeikh Ahmad Syurkati dan H.O.S Tjokroaminoto merupakan tokoh-tokoh yang memberikan pengajaran dan tempat bertanya di JIB, sehingga Natsir dapat dekat dengan tokoh-tokoh tersebut. Natsir berkata :

"Ada tiga guru yang mempengaruhi alam pikiran saya. Pertama, Tuan Hassan -

\begin{abstract}
pimpinan Persis (Persatuan Islam) Bandung- Haji Agus Salim, dan Syech Akhmad Syoekarti -pendiri Al Irsyad. Kalau ke rumah tuan Hassan, saya selalu menanyakan suatu persoalan, lalu kami diskusi. Dari situ saya diberi sejumlah buku, seperti buku tafsir AlFurqon, atau tafsir The Holy Qur'an karya Muhammad Ali." (Tempo, 1993: 82)
\end{abstract}

Perjalanan hidup Natsir di Bandung merupakan salah satu titik yang sangat bepengaruh dalam terbentuknya pemikiran dan sikap Natsir selain alam Minangkabau tadi. Nata (1999: 76) menyebutkan, ketika hidup di Bandunglah ia banyak membaca tulisan-tulisan dari ulama Internasional seperti Hassan Al-Banna, Amir Syakib Arselan, Rasyid Ridha dan Muhammad Abduh, yang secara tidak lansung mempengaruhi pemikiran Natsir dalam melihat Islam. Adapun pengaruh lansung terhadap pemikiran Natsir adalah datang dari ulama dan tokoh nasional di Indonesia seperti Ahmad Hassan, H.Agus Salim, Syeikh Ahmad Syurkati dan H.O.S Tjokroaminoto.

Perkembangan organisasi dan media pada saat itu turut dalam mempengaruhi gaya berpikir Natsir. Melalui organisasi seperti Jong Islamieten Bond (JIB) Bandung dan Persatuan Islam (Persis), ia mengasah kemampuan berpikir dan analisanya dalam menyelesaikan suatu masalah.

Melalui media cetak seperti Pandji Islam, Pedoman Masyarakat dan Pembela Islam yang sedang berkembang pada saat itu, Natsir melimpahkan pemikiran-pemikirannya mengenai ajaran-ajaran Islam, 
termasuk posisi Islam dalam negara. Melalui media cetak jugalah Natsir dan Ahmad Hassan giat dalam mengenalkan Islam kepada masyarakat dan menangkis serangan-serangan yang ditujukan oleh lawan-lawan untuk menjatuhkan Islam.

Pemikiran Natsir tentang kenegaraan juga tak lepas dari konteks politik saat itu. Salah satu pemicunya adalah polemik dirinya dengan Soekarno pada 1930-an sampai 1940an.

Dalam seri buku Tempo (2011) mengenai Natsir, dinyatakan bahwa pada awalnya Natsir pernah terpesona dengan ajaran nasionalisme yang dikumandangkan oleh Partai Nasional Indonesia dengan Soekarno sebagai pimpinan besarnya. Natsir sering menghadiri rapat Partai Nasional Indonesia tersebut. Namun semua berubah ketika Natsir sering mendengar cemoohan terhadap Islam dalam kampanye Partai Nasional Indonesia pada kurun 1920-1930. Cemoohan yang dilontarkan seperti mencela hukum poligami, berhaji ke Digul lebih baik dari pada berhaji ke Mekkah, memalingkan kiblat ke Demak dan lain sebaginya. Dari sini Natsir mulai tidak sepaham dengan pemikiran kaum nasionalis termasuk Soekarno. Dan ketika itulah Natsir sadar bahwa gerakan kebangsaan yang dipelopori oleh Soekarno dan kawankawan menyemai bibit kebencian terhadap Islam.

Polemik Natsir dan Soekarno yang pada awalnya masalah kebangsaan, bergeser kemasalah agama dan negara. Soekarno menjadikan Turki dan Kemal Attaturk sebagai alasan mengenai dipisahkannya agama dan negara. Soekarno membela perkembangan Turki adapun Natsir mencelanya. Deliar Noor yang dikutip oleh Puar (1978 : 367) berpendapat bahwa Soekarno mengutip penilaian yang ditulis oleh orang Barat, dan ketika ia mengutip pendapat seorang pimpinan Turki (yaitu Halide Edib), ia mengutipnya seenaknya seperti yang dikatakan Natsir untuk mencari pembenaran pendapatnya sendiri.

Di bagian lain Soekarno juga menyatakan pendapatnya dengan mengutip perkataan Syeikh Abdurrazik yang berpandangan bahwa Rasulullah hanya mendirikan agama, bukan Negara. Mengenai hal ini Natsir menjawabnya bahwa mengenai pemisahan antara agama dan negara sebenarnya tidak perlu diributkan lagi, karena yang sudah terang bagi umat Islam adalah Negara sudah mesti ada, baik ada atau tidaknya suruhan yang tegas dari Rasulullah, dan Agama Islam memiliki beberapa peraturan dan dasar-dasar peraturan yang harus dijalankan dalam mengurus Negara tersebut (Natsir, 1973 : 484). Pandangan Natsir tersebut berkaitan dengan bahwa Islam memiliki peraturan dan pedoman hidup yang jelas dalam mengatur masyarakat ataupun negara dengan batasan-batasan atau hukum-hukum yang dimiliki, sehingga bagaimanapun aturan tersebut harus dilaksanakan dalam suatu negara dengan ada atau tidaknya suruhan yang tegas dari Rasulullah.

Penjelasan di atas memperlihatkan, pemikiran Natsir mengenai negara banyak dipengaruhi oleh nilai-nilai keIslaman yang ia terima, mulai dari kecil hingga dewasa. Pengaruh-pengaruh tersebut datang dari banyak hal, mulai dari pengaruh lingkungan masa kecil Natsir di Minangkabau yang berasal dari keluarga religius, pengaruh pemikiran 
pengaruh tokoh-tokoh nasional (Ahmad Hassan, H.Agus Salim, Syeikh Ahmad Syurkati dan H.O.S Tjokroaminoto) dan internasional (Hassan Al-Banna, Amir Syakib Arselan, Rasyid Ridha dan Muhammad Abduh), pengaruh organisasi dan partai politik tempat Natsir bernaung (Jong Islamieten Bond (JIB), Persatuan Islam (Persis), dan partai politik Masyumi), serta pengaruh dari kondisi perpolitikan saat itu yang membuat pandangan Natsir berubah, yang awalnya menerima menjadi penentang Pancasila. Proses munculnya pemikiran Natsir tentang negara khususnya Islam dan negara lahir dari suatu proses yang panjang.

\section{F. KESIMPULAN}

Dari penjelasan di atas dapat dikatakan, dalam pandangan Mohammad Natsir suatu negara sudah seharusnya memiliki akar yang kuat dan memenuhi kebutuhan masyarakat yang tinggal di dalamnya. Akar kuat tersebut menurut Natsir yaitu syariat Islam. Dengan dasar negara yang kuat akan menghasilkan negara yang kuat

\section{Daftar Kepustakaan}

Dhofier Al-Maududi, A. (1975). Hukum dan Konstitusi Sistem Politik Islam. Bandung : Mizan.

Dzulfikriddin. (2010). Mohammad Natsir Dalam Sejarah Politik Indonesia, Peran dan Jasa Mohammad Natsir Dalam Dua Orde Indonesia. Bandung: PT.Mizan Pustaka.

Jameelah, M. (1982). Islam \& Modernisme (Kritik Berbagai karena bagi Natsir, negara hanya sebagai alat untuk menjalankan syariat Islam. Mengenai bentuk negara, Natsir tidak terpaku pada bentuk negara apapun, namun condong kepada bentuk negara kesatuan seperti yang ia praktekkan dalam melahirkan Negara Kesatuan Republik Indonesia (NKRI) melalui Mosi Integral.

Bagi Natsir, kepadala negara tidak harus menggunakan kata khalifah dan harus keturunan Quraisy. Menurutnya, gelar apapun boleh digunakan seperti khalifah, amirul mukminin, presiden dan lain-lain. Adapun kriteria untuk mejadi pemimpin menurut Natsir adalah dengan dilihat dari agamanya, sifat, tabiat, akhlak dan kecakapan dalam memangku jabatan, bukan pada bangsa dan keturunannya.

Lahirnya pemikiran Natsir ini dipengaruhi oleh beberapa faktor, mulai dari faktor lingkungan masa kecil Natsir di Minangkabau, pengaruh tokoh Islam nasional maupun internasional, sosialisasi politiknya di organisasi-organisasi dan partai politik Islam, serta konteks politik saat itu.

\section{Sekularisasi Dunia Islam).} Surabaya : Yayasan Kampusina.

Luth, T. (1999). M. Natsir, Dakwah dan Pemikirannya. Jakarta : Gema Insani.

Santosa, O (ed.). (2004). Mohammad Natsir Islam Sebagai Dasar Negara. Bandung: Sega Arsy.

Setyaningsih, E. (2016). Perjuangan Dan Pemikiran Politik Mohammad 
Natsir (1907-1993). Jurnal TAPIs, $12(2)$.

Sirajuddin. (2007). Politik

Ketatanegaraan Islam, Studi

Pemikiran A.Hasjmy. Yogyakarta: Pustaka Pelajar

154 ' 'man, S. (2010). Islam dan Negara Menurut M. Natsir dan Nurcholish Majid. Jurnal Dakwah, Vol. XI No. 2

Suhelmi, A. (2002). Polemik Negara Islam "Soekarno Versus Natsir". Jakarta: Teraju.

Mahfud. (2008). "Mosi Integral Natsir dan Sistem Ketatanegaraan Kita", (Disampaikan pada seminar Refleksi 58 Tahun Mosi Integral Mohammad Natsir- Merawat NKRI Menghempang Potensi Disintegrasi. Diselenggarakan di Universitas Jenderal Soedirman, Poerwokerto, tanggal 9 Juli.

Mohammad, H dkk. (2006). TokohTokoh Islam yang Berpengaruh Abad 20. Jakarta: Gema Insani Press.

Nata, A. (1999). Tokoh-Tokoh Pembaharuan Pendidikan di Indonesia. Jakarta : Gema Insani Press.
Natsir, M. (1973). Capita Selecta. Jakarta : Bulan Bintang. . (1968). Persatuan Agama dan Negara. Jakarta : Media Dakwah. .(2001). Agama dan Negara Dalam Perspektif Islam. Jakarta : Media Dakwah

Puar, A. (1978). Mohammad Natsir 70 Tahun Kenang-Kenangan Kehidupan \& Perjuangan. Jakarta : Pustaka Antara.

Ritchie, J., \& Lewis, J (ed). (2003). Qulitative Research Practice: A Guide for Social Science Students and Researches. London: Sage Publication.

Tempo. (1993). M.E.M.O.A.R Senarai Kiprah Sejarah. Jakarta : PT. Pustaka Utama Grafiti. 2011. Natsir, Politik Santun di Antara Dua Rezim. Jakarta : PT. Gramedia.

Thaha, A. (1996). Islam \& Negara dalam Politik Orde Baru. Bandung : Gema Insani Press.

Yusafrida. (2012). Kiprah Politik Mohammad Natsir. Jurnal TAPIs Vol.8 No.2. 